\title{
REGULATING THE TERMINATION OF EMPLOYMENT OF ABSCONDING EMPLOYEES IN THE PUBLIC SECTOR AND PUBLIC EDUCATION IN SOUTH AFRICA: A PRELIMINARY VIEW
}

\section{Introduction}

South Africa is a constitutional democracy with a justiciable Bill of Rights. Section 23(1) of the Bill of Rights entrenches the right to fair labour practices. National legislation, including the Labour Relations Act 66 of 1995 (LRA), gives detailed context to the constitutional right to fair labour practices, including the right not to be unfairly dismissed, provided for in section 185(a). In terms of section 186(1) of the LRA a dismissal means "an employer terminated a contract of employment with or without notice".

Section 188 provides further that a dismissal that is not automatically unfair, is unfair if the employer fails to prove that the dismissal is for a fair reason related to the employees conduct, or capacity, or based on the employer's operational requirements, and the dismissal had been in accordance with a fair procedure. These provisions give effect to the Termination of Employment Convention 158 of the ILO (see in particular articles 3 to 14) and the constitutional right to fair labour practices contained in section 23(1) of the Constitution.

In the Public Service Act 103 of 1994 (PSA), section 17(3)(a)(i) provides that an employee other than an educator who absents himself without permission of his head of department, office or institution for a period exceeding one calendar month, shall be deemed to have been dismissed from the public service on account of misconduct with effect from the date immediately succeeding his last day of attendance at his place of duty.

In a similarly worded provision, section 14 of the Employment of Educators Act provides for the deemed dismissal of an educator who is absent from work for a period exceeding fourteen (14) consecutive days without permission of the employer.

The issue that is addressed in this note is whether or not the provisions dealing with unexplained absence in the South African national and provincial public sector does not unreasonably limit the constitutional right to fair labour practices, and whether the provisions do not circumvent the essential provisions of Convention 158 of the ILO. The public service at local level is not affected, since the Public Service Act is not applicable to such employees. Such employees enjoy the same legal protection as private-sector employees. This note therefore explores how these issues 
may be addressed, by firstly considering the general legal position in relation to employees who are absent without leave as well as absconding employees. Secondly the "deemed dismissal" provisions in the public sector are discussed. Thirdly, the constitutionality of the "deemed dismissal" provisions are briefly considered. The note concludes by providing an analysis of the courts' approach to this matter, as well as making certain recommendations regarding the way forward.

\section{Absence without leave and absconding employees: The general position}

Absence without leave constitutes misconduct. The requirement that a dismissal for such absence should be procedurally and substantively fair is emphasized in terms of section 188 of the LRA. Even if a lesser sanction than dismissal is imposed, the imposition of such a sanction may be challenged as an unfair labour practice in terms of section 186(2)(b), which provides that disciplinary action short of dismissal in respect of an employee may constitute an unfair labour practice.

In an instance where an employee absconds from the workplace with no intention to return, such employee repudiates the contract of employment. Repudiation amounts to breach of a material term of the contract, which gives the employer the right to resile from the contract by cancelling it.

In SABC v CCMA (2001 22 ILJ 487 LC) the Labour Court held that desertion (or absconding) constitutes a breach of the employment contract by repudiation of the contract. Repudiation does not bring about the termination of the contract. It simply entitles the innocent party (the employer in this instance) to acknowledge the repudiation and then to accept it. By electing to accept the repudiation, the contract terminates, but this is a juridical act of the employer. When the employer terminates the contract in this way, the termination amounts to a dismissal, and section 188 applies. The dismissal must therefore comply with the requirements of substantive and procedural fairness (par 492-493 of the judgment).

In the Labour Appeal Court judgment of SACWU v Dyasi (2001 7 BLLR 731 LAC 735) the court held that the dismissal of a deserting employee was procedurally unfair, because the employee was not afforded a disciplinary inquiry prior to the dismissal. In this case the whereabouts of the employee were known to the employer. Concerning a deserting employee who cannot be traced the court (albeit obiter) opined as follows:

"When the employee deserts and cannot be traced, the employer has no practical choice other than to accept the repudiation. Where there is no real choice, it can probably be argued that the employer did not terminate the contract."

This was further developed in SATAWU obo Langa $v$ Zebedelia Bricks (Pty) Ltd (2011 32 ILJ 428 LC). In this case the court held that an unequivocal act of absconding automatically terminated the contract of employment, and in such a case an employee is not dismissed. The facts of the case were that employee who had participated in an 
unprotected strike, was dismissed. Subsequent to the dismissal the employees were reinstated. Despite the reinstatement the employees did not report for duty, but instead gathered at the entrance of the premises of the employer. They also intimidated the employees and customers, leading to an interdict being obtained against them. They still did not return to work. The employees then referred a dismissal dispute to the CCMA. The commissioner held that the CCMA had no jurisdiction to entertain the dismissal dispute, since it concerned dismissal for participation in an unprotected strike. The case was thereupon referred to the Labour Court. Some of the applicants maintained that they had been intimidated, and therefore did not return to work. The court held that these employees were dismissed in a procedurally unfair manner. The applicants, who had not been intimidated, had deserted and had unilaterally terminated their employment. The court was of the view that "desertion in its truest sense automatically terminates a contract of employment. It cannot be seen as a form of misconduct".

The court was, with respect, incorrect to make a factual finding that the employees had deserted their employer. In any event, even if the finding was that the employees had in fact deserted the employer, the construction that the contracts automatically terminated, is not in principle correct. The employees repudiated the contracts, and the employer must accept the repudiation. If the employer does not cancel the contract the contract has not terminated yet. For all intents and purposes the employees in this case had been dismissed.

\section{The public sector: Enter the deeming provision}

The cases referred to indicate the difficulties that a private sector employer experiences when faced with the desertion of an employee. In the public sector, including public education in South Africa, the legislature intervened. As pointed out above desertion in not regulated by legislation in the public sector at local level. The deemed dismissal provisions are contained in section 17 of the Public Service Act and section 14 of the Employment for Educators Act respectively, and are accordingly detailed and subsequently discussed below.

Section 17 of the Public Service Act (PSA) deals with termination of employment. In this regard subsection 3(a) and (b) provide:

"(a)(i) An employee, other than a member of the services or an educator or a member of the Intelligence Services, who absents himself or herself from his or her official duties without permission of his or her head of department, office or institution for a period exceeding one calendar month, shall be deemed to have been dismissed from the public service on account of misconduct with effect from the date immediately succeeding his or her last day of attendance at his or her place of duty.

(ii) If such an employee assumes other employment, he or she shall be deemed to have been dismissed as aforesaid irrespective of whether the said period has expired or not.

(b) If an employee who is deemed to have been so dismissed, reports for duty at any time after the expiry of the period referred to in paragraph (a), the relevant executive authority may, on good cause shown and 
notwithstanding anything to the contrary contained in any law, approve the reinstatement of that employee in the public service in his or her former or any other post or position, and in such a case the period of his or her absent from official duty shall be deemed to be absence on vacation leave without pay or leave on such other conditions as the said authority may determine."

Section 14 of the Employment for Educators Act (EEA) similarly provides:

\section{"14. Certain educators deemed to be discharged -}

(1)An educator appointed in a permanent capacity who -

(a) is absent from work for a period exceeding 14 consecutive days without permission of the employer;

(b) while the educator is absent from work without permission of the employer, assumes employment in another position;

(c) while suspended from duty, resigns or without permission of the employer assumes employment in another position; or

(d) while disciplinary steps taken against the educator have not yet been disposed of, resigns or without permission of the employer assumes employment in another position,

shall, unless the employer directs otherwise, be deemed to have been discharged from service on account of misconduct, in circumstances where -

(i) paragraph (a) or (b) is applicable, with effect from the following day immediately after the last day on which the educator was present at work; or

(ii) paragraph (c) or (d) is applicable, with effect from the day on which the educator resigns or assumes employment in another position, as the case may be.

(2) If an educator who is deemed to have been discharged under paragraph (a) or (b) of subsection (1) at any time reports for duty, the employer may, on good cause shown and notwithstanding anything to the contrary contained in this Act, approve the re-instatement of the educator in the educator's former post or in any other post on such conditions relating to the period of the educator's absence from duty or otherwise as the employer may determine."

In terms of section 14 of the EEA the period of absence is not a calendar month, as is required in section 17 of the PSA, but 14 consecutive days. It is apparent that the ambit of these two provisions is wider than when dealing only with absconding employees. They include longer-term absence without leave, as well as temporary impossibility of performance where the permission of the relevant superior has not been obtained.

The effect of the statutory provisions in the public service and public education is that, provided the jurisdictional requirements are met, the employment contract is terminated by operation of law. In section 14(1)(a) of the EEA, for example, the objective jurisdictional requirements to be met are: (i) that the employee must be permanently employed, (ii) that the employee must have been absent longer than 14 consecutive days, and (iii) that the absence must be without permission of the employer. At a glance, and in a peremptory fashion, this section seems to regard the employee as deemed dismissed if all the jurisdictional requirements were met. Such an employee will then have to invoke section 14(2) of the EEA should he or she wish to be reinstated or re-employed on good cause shown. Yet, on closer reading of 
section 14(1), it seems that a discretion is afforded to the employer by virtue of the phrase "unless the employer directs otherwise". At least two implications can be inferred from this phrase. Firstly, it could mean that the employer could "direct" that the conduct of the employee be treated as an ordinary misconduct. Secondly, it could mean that the employer may "direct" that the absenteeism started on a date different to that indicated in section 14(1). Either way, it does not seem plausible that it could have been the intention of the drafters to include this superfluous phrase in a peremptory provision, since on the one hand it does not accord satisfactorily with the purpose of section 14(1) on the whole, and on the other hand a discretion is afforded to the employer in section 14(2) anyway.

Since the termination of employment is not based on the employer's decision, there is no dismissal, and the employee is thus not entitled to a disciplinary enquiry. The termination of employment is also not subject to judicial review, since no discretion is exercised by a public authority. However, if one is to interpret the phrase "unless the employer directs otherwise" in section 14(1) to mean that a discretion is introduced, then the judicial review process ought to be an option for the employee.

In all other circumstances the termination of employment takes place automatically, by the operation of law (in this regard see Mahlangu $v$ Minister of Sport and Recreation 20105 BLLR 551 LC). It is an objective question whether the requirements of the statutory provision are satisfied. If a factual dispute arises in relation to the objective jurisdictional facts, then such a dispute is justiciable by a court of law.

Both legislative provisions allow for subsequent reinstatement on good cause shown, but the courts confirmed that the decision to reinstate does not constitute a dismissal. It was held that it was a reviewable exercise of statutory power, and accordingly reviewable under the Promotion of Administrative Justice Act, in De Villiers v Head of Department: Education, Western Cape Province (2009 30 ILJ 1022 LC). This view found support in the SCA judgment of Phenithi $v$ Minister of Education (2000 11 BLLR 1314 (SCA)). Already in the case of Hospersa $v$ MEC for Health (2003 12 BLLR 1242 (LC)) the Labour Court expressed concern about these provisions, and the court referred to the "draconian procedure" (1249E).

It was the court's view that reliance on the applicable disciplinary code was a less restrictive method of achieving the same objective of enquiring into and remedying an employee's absence from work, and that the sections must be invoked sparingly, and particularly when the employer has no other alternative. For example, when the respondent was unaware of the whereabouts of the employee, or could not contract her or him (1249F-G). These were obiter remarks and the South African courts continue to give effect to the provisions.

\section{The constitutionality of the provisions}

In Phenithi $v$ Minister of Education (supra), the SCA held that section 14 of the Employment for Educators Act was not unconstitutional. The court held that "the provision creates an essential and reasonable mechanism for the employer to infer 'desertion' when the statutory 
prerequisites are fulfilled". Where that is not the case, the statute provides ample means to rectify or reverse the outcome (par 19).

The Court accepted that education's services under 14(1)(a) of the EEA materially and adversely affect such educators' rights. It does not necessarily make section 14(1)(a), which does not require the right to a hearing unconstitutional. The Court referred to the fact that section 14(2) provides the educators with an opportunity to be heard and reinstated, provided he or she is able to show good cause as to why the employer should reinstate.

Referring to evidence that the provisions of section 14(1) are necessary in the education department, because of the effect of an educator's absence without leave on the rights of children to education, the Court concluded that the limitation (if there is one) was reasonable and justifiable in an open and democratic society, based on human dignity, equality and freedom in terms of section 36(1) of Constitution.

Concerning the section 17 deemed-dismissals provision, the case of Grootboom v National Prosecuting Authority (2014 TLT 121 CC) reached the constitutional court. The constitutionality of section 17(3) was challenged and the Court accordingly had to interpret section 17(3) in a manner best compatible with the Constitution.

The facts were that the employee had left the country to study abroad while on suspension. He was discharged in terms of section $17(3)$ of the PSA. The Constitutional Court confirmed that the discharge was not an administrative act capable of review (par 16). The Court held, however, that the employee did not absent himself from his official duties. He had already been suspended and thereby had been forbidden to perform any official duties. He was also instructed not to come to work. The Court concluded that the suspension rendered him absent and section 17(3) was not applicable. The Constitutional Court was not required to pronounce on the constitutionality of the deemed-dismissal provision. It recognised that in these circumstances a public sector employee's services are terminated without notice or disciplinary hearing. The Court accepted that the section has the effect of termination of employment (for misconduct) without a hearing, and that it impinges on the section 23 of the Constitution. The proper scope of application needs to be determined, and the case before the Court does not cover the position where the employer had suspended the employee. It is clear that the Court adapted a narrow approach of interpretation to limit the ambit of the section.

\section{$5 \quad$ Analysis and recommendations}

In Phenithi the SCA concluded that section 14 of the EEA was not unconstitutional. One of the reasons advanced concerned the balancing of the rights of the child. This reason is not present when the constitutionality of section 17(3) is considered. Other constitutional imperatives may play a role, but it is submitted that "draconian measures" (as per Hospersa) of section 17 are not required to limit the public-service employees' right to a fair hearing, and therefore his or her right to fair labour practices. Moreover, preferring the child's right to education with the right to fair 
labour practice of a public educator needs a more fundamental analysis than the consideration given to it in Phenithi.

It is not only the right to a hearing prior to dismiss that is excluded by section 17 (of the PSA) and section 14 (of the EEA). These sections remove the employee's right of access to conciliation and arbitration, and compel an employee who did not desert to take a decision not to reinstate him or her on administrative review. There is furthermore no requirement that the consideration to determine good cause needs to be done following a hearing, where the employee is allowed to be present, or represented by his or her trade union representative or another fellow employee. This is a further limitation of the constitutional right to fair labour practices. There are less restrictive means to achieve the same objective. The remarks in Hospersa are instructive in this regard. Various options can thus be explored in order to make the process less burdensome for the deemed dismissed employee. What makes it slightly problematic is that both sections refer to some higher authority that must deal with the appeal. In the PSA that authority is the executive authority, and in the EEA is it the employer. For purposes of the EEA, and particularly for section 14, the employer is defined as the Director-General if the employee is in the service of the Department of Basic Education, and the Head of Department if the employee is in the service of a provincial department of education.

It is recommended that the PSA and EEA be amended to the effect that when an employee whose services were terminated returns, a hearing will be conducted. This hearing does not need not be conducted by the relevant executive authority, or employer as the case may be, but by the authority that would normally exercise discipline, or convene incapacity hearings in the department. This will accelerate the process and may further result in the fairer management of deemed dismissals in the public sector. After all, one of the purposes of the LRA (imported into other applicable employment laws) is the speedy resolution of disputes. The purpose of the hearing will be to determine whether the employee should be reinstated or re-employed, and whether or not such reinstatement or re-employment should be retrospective.

Should the proposed internal hearing as described above, result in a decision not accepted by the particular employee whose services had been terminated, the option of challenging the decision at bargaining council should be available in terms of the applicable legislation. Conciliation and arbitration should then be the dispute-resolution process that will be resorted to. The necessity of launching a review application in the Labour Court will accordingly fall away when the refusal to reinstate is challenged. Only a relevant amendment to the PSA and EEA will be required, and not an amendment to the Labour Relations Act. It is submitted that all the roleplayers will support such a procedure which will not necessarily infringe on the constitutional right to fair labour practices.

Adriaan van der Walt

David Abrahams

Thanduxolo Qotoyi

Nelson Mandela Metropolitan University, Port Elizabeth 